\title{
THE IMPLEMENTATION OF KNOW-WANT-LEARN (K-W-L) STRATEGY IN TEACHING READING AT ELEVENTH GRADE OF SMA NEGERI 3 SINGARAJA
}

\author{
Putra, I.P.K.A.P \\ English Education Department, Ganesha University of Education \\ e-mail: putraiputu@yahoo.co.id
}

\begin{abstract}
This study aimed at describing the implementation of Know-Want-Learn (K-W-L) strategy used by one of the English teachers in SMA Negeri 3, Singaraja, Bali. In this study, the subjects of the study were the students of SMA Negeri 3 Singaraja especially the eleventh grade, and, an English teacher. The present study employed qualitative design. The methods of data collection were classroom observation and, questionnaire. The findings showed that there were 3 stages of the implementation of Know-WantLearn (K-W-L) strategy in SMA Negeri 3 Singaraja namely pre-teaching, whilstteaching and post-teaching. There were several activities from each stage. In preteaching, teachers prepare teaching materials and also media to implement K-W-L strategies. In whilst-teaching, in this stage the teacher implements steps from K-W-L. The result of the questionnaire, showed that Know-Want-Learn (K-W-L) strategy is one of the brilliant alternative strategy that could be used by teacher, because KWL (Know, Want, Learn) developed some ideas about the text before reading the whole text, and focus on finding the important points of the text. It means before the student starts to read the text, they need to use their prior knowledge and continue to set their want or interest of the text.
\end{abstract}

Keywords: K-W-L strategy, reading comprehension

\section{INTRODUCTION}

Teaching English should be done properly and a good preparation is needed before going to the classroom. Teaching English needs high skill and dedication in teaching. Teachers of English for foreign learners need to have a great understanding of how students think and use the language. Mutsliah (2016) defined that the teachers play an important role in order to achieve the better improvement in language skills. In English subject, there are many topics that need to be learnt by students. All of the topics such as language expressions and English texts are integrated with four English language skills namely listening, speaking, reading, and writing.

Byrnes (1998) stated that reading is an interactive process that goes on between the reader and the text, resulting in comprehension. The reader uses knowledge, skills, and strategies to determine what that meaning is. In addition, Byrnes (1998) stated the aim of teaching reading is to develop the students reading skill so that they can read English text effectively and efficiently. To be able to read effectively and efficiently, students should have a particular purpose in their mind before they interact with the text. The main purpose of reading a text is to comprehend and obtain much information. To understand a text a student must have a good comprehension of vocabulary of the target language but it does not mean merely learning the words. 
According to Harris and Smith (2016), in daily life, it is very important to get information from every reading passage, especially in learning English. Reading is one of the basic skills in English which is not simply translated word by word but need to be acquired during language course. Therefore, when the students learn to read, they should be able to comprehend the readings text during the process of reading. Based on Sinambela, Manik, and Pangaribuan (2015), the condition in Indonesia, it is certainly not easy to teach the English reading activity to Indonesian student whose language system is different. Many students find some difficulties when they are reading. Reading in their mother language is much easier than the target language because they have known the vocabulary and the structure of their mother language well. Reading comprehension is very important for the students because they have to read a great number of reading materials in their learning process.

In order to achieve the better improvement in reading skill, there are various strategies which can be implemented and continued into the process of learning. One way to lead it into the process is Know, Want, Learn (KWL) strategy. The researchers believe that know-want-learn (K-W-L) strategy can be trusted to direct students to have deeper thinking because know-want-learn (K-W-L) strategy in this case is able to guide students to draw conclusions based on the students' initial knowledge. In addition, Ogle (1986) stated that, know-want-learn (K-W-L) strategy is also able to direct students to be able to provide opinions and arguments. In this study, the topic taken is Hortatory Exposition, so KWL is able to help students to provide arguments based on the text they have read.

To make sure that the strategy can be implemented in Senior high school, a case observed in a senior high school in Singaraja, Buleleng, Bali. The school is SMA Negeri 3 Singaraja. Based on preliminary observation, K-W-L strategy is a program which is applied in that school. Realizing the K-W-L Strategy has been applied in SMA Negeri 3 Singaraja, and the result create good atmosphere of learning, deep research is needed in the school in order to get comprehensive information on how know-wantlearn (K-W-L) strategy is implemented and also to know the response of the student in SMA Negeri 3 Singaraja toward K-W-L Strategy.

\section{METHOD}

This research discussed the implementation of know-want-learn (K-W-L) strategy in teaching reading at eleventh grade of SMA Negeri 3 Singaraja. Based on the purpose of the study and the research question, the study was conducted in the form of qualitative study. This study took place in SMA Negeri 3 Singaraja. Since the research was conducted at the eleventh-grade students of SMA Negeri 3 Singaraja, then the subjects of the study were the students, and the English teacher. Based on the purpose of the study, the object of the study is the implementation of know-want-learn (K-W-L) strategy in teaching reading at eleventh grade of SMA Negeri 3 Singaraja and about the students' responses about the implementation of K-W-L Strategy. This study involves some technique of collecting the data. Those are observation, this was considered as the main data collection. The second one is questioner, it was conducted to get students opinion and argument about the KWL Strategy. The process of data collection requires the researcher to follow the steps in collecting the data. Firstly, preparing the instruments, selecting the informants or subject of the study, investigating data through the technique and strategy applied in the research, in this study, observing the 
classroom, collecting information needed and analyzing the data, and making conclusion. After getting the data by collecting them in various techniques, the data is analyzed qualitatively in the form of description. However, the data in the form of scores which was assessed through close questionnaire.

\section{FINDING AND DISCUSSION}

As what has been stated in chapter one the purposes of the study were to described and analyzed the implementation of Know-Want-Learn (K-W-L) strategy in SMA Negeri 3 Singaraja. In order to fulfill those purposes, the data were collected the results of observations in the school environment and in the teaching and learning process in the classroom and also from the questionnaire that answered by the student in order to know the response based on students' perspective about Know-Want-Learn (KW-L) Strategy. The teacher conducted the K-W-L strategi in 3 classes, those were XI IBB 1, XI IBB 2, and XI MIPA 4. there were several steps in implementing the strategy namely (1) Choose the topic and text, (2) create a K-W-L chart, (3) what I know (K) stage, (4). what I want to know (W) stage, (5) what I have learn (L) stage, and (6) Discuss the information that students recorded in the L column.

In the first step, the teacher had to choose fictional and informational texts that were appropriate for the students. In second steps, the teacher wrote down the K-W-L chart on the whiteboard. The chart was divided into 3 such as $\mathrm{K}$ (Know), W (Want) and L (Learn). In XI IBB 1, XI IBB 2, and XI MIPA 4 classes, the teacher created the K$\mathrm{W}-\mathrm{L}$ chart on the white board. The reason why the teacher created the K-W-L chart on the white board was to make sure that the students had a full access to read the notes that stuck by the students. In what I know stage, the teacher asked the students in those 3 classes to make a group consist of 5 members. The reason why the teacher applied group work was because the member of XI IBB 1 was quite a lot. After the students divided themselves into groups consist of 5 members then the teacher took out the PostIt Notes and distributed it to the students. Meanwhile, the teacher distributed the post-it notes to the students and asked the students to write down everything they know about the topic. In order to maximize the opportunities, the teacher distributed 2 post-it notes for each group. In what I want to know stage, the students were ordered to write about what they wanted to know about the topic. During the W (want to Know) activities, the researcher monitored the students' work. The students discussed with their group and based on the observation the students were looked very active and enthusiastic in $\mathrm{W}$ (want to Know) activity. In what I have learn (L) step, the teacher asked the representative of the group to came forward and took the text and distributed the text to the students. Than the teacher guided the students to the last step of KWL strategy that is filling the L column (what they have learned). The students should look for the answers to the questions in the $\mathrm{W}$ column while they were reading. They could fill out the L column on their own chart either during or after reading. In the last step, the teacher asked the students to draw a conclusion about the what their prior knowledge that they wrote in K Column, then they drew a conclusion about what they want to know that already written in $\mathrm{W}$ column and the last they drew a conclusion about what they have learnt in based on reading material and present it orally. This was done in order to find out the students' comprehension in reading skills.

The result of questioner explained that Know-Want-Learn (K-W-L) Strategy could help the student in solving kind of problems in the classroom. For instance, K-WL Strategy develops the classroom situation, the students' motivation and attitude 
towards English lesson is getting better especially in reading class. Students become more active participants during the teaching learning process because they interacted with their friends in group.

\section{DISCUSSION}

As explained previously, all stages of Know-Want-Learn (K-W-L) are provided for teaching reading as already explained above. In the classroom, all Know-Want-Learn (K-W-L) are directed to make the lesson well understood, so the use of the Know-WantLearn (K-W-L) aimed to helped the students understand the concept of reading better. In the implementation of K-W-L strategy before the student read the passage or text, the teacher asked the student to write down their prior knowledge and asked them to write down everything they would like to know. It was because it was not easy to read the English text without any preparation. Moreover, if it was done without preparation, the concepts become very abstract and as a result it was very difficult to be understood by the students. This is actually a way of how the students can retrieve the information from their prior knowledge and connect it with some new information that they got from the passage.

Based on the literature review above which explained about the standards of KnowWant-Learn (K-W-L) strategy, the implementation of K-W-L in SMA Negeri 3 Singaraja is considered precise. The implementation of Know-Want-Learn (K-W-L) strategy by the teacher in SMA Negeri 3 Singaraja were categorized into 6 points out of 6 points of standards. Based on the observation, Know-Want-Learn which was implemented in SMA Negeri 3 Singaraja gives positive impact to both teacher and students. By implementing this strategy at the school, the teacher is able to set the reading purposes. Besides that, it helped the teachers to monitor the prior knowledge of the student before they get the new information and the teacher was able to know the students' knowledge after they read the passage or text.

Based on the observation on Know-Want-Learn (K-W-L) strategy, the teacher also developed the way of thinking of students. It is supported by the education system in Indonesia which requires students to think deeper or known as Higher Order Thinking Skills. Moreover, based on Heong, et al (2011) explained about Higher Order Thinking Skills, higher order thinking demands someone to apply new information or knowledge that he has got and manipulate the information to find possible answer in new situation. In relation with the implementation of Know-Want-Learn (K-W-L) strategy that implemented in SMA Negeri 3 Singaraja, it was found that, the students developed their knowledge that they already have and integrated it with the new information or knowledge they just got from a source. It is clear that, Know-Want-Learn (K-W-L) strategy is able to develop the Higher Order Thinking Skills of the students.

In addition, the statement above is supported by Brookhurt (2010) opinion about Higher-Order Thinking Skills. HOTS is conceived as students being able to relate their learning to new other elements beyond those they were taught to associate with it. Again, it is in relation with the finding on the implementation of Know-Want-Learn (KW-L) strategy in SMA Negeri 3 Singaraja, it was found that, K-W-L strategy was able to combined the prior knowledge of the students with new knowledge because in K-WL strategy there was K (Want I Know) stage which aimed to know what the students already know about topic. Then there was L (What I Learn) stage which in this stage students wrote all the information that they got from a source or various sources. 
Based on Brookhurt (2010) explanation about the aspects of HOTS, there are several aspects such as (1) problem solving ability, (2) critical thinking, (3) creative thinking, (4) reasoning, and (5) decision making. In relation with aspect of HOTS above, the researcher found the teacher applied HOTS. In problem solving, K-W-L strategy in this case serves to enabled the prior knowledge of students, what they already know or learn before. This could be seen in the "K". In critical thinking aspect, $\mathrm{K}-\mathrm{W}-\mathrm{L}$ helped students to confirmed the knowledge that has been reviewed. Student confirmed by giving questions then read text given by the teacher, then confirmed with the answers from text or prior knowledge of the students (' $\mathrm{W}$ ' and ' $\mathrm{L}$ ' activity). In creative thinking aspect, $\mathrm{K}-\mathrm{W}-\mathrm{L}$ in this case aimed students to created new way of thinking, new ideas, new knowledges and answers obtained after reading ('L' activity). In reasoning, K-W-L helped students to be able to give opinions and arguments. In this study, the topic taken was about Hortatory Exposition. So, K-W-L helped students to be able to give arguments as well as opinions based on reading sources ('L' Activity). The last is decision making, K-W-L in this case guided students to drew conclusions based on their prior knowledge, related questions that made by the students in ' $\mathrm{W}$ ' activity and also from the answers in ' $\mathrm{L}$ ' activity that obtained from the sources of reading.

Besides, based on the result of questioner, it is explained that Know-Want-Learn (K-W-L) Strategy could help the student in solving kind of problems in the classroom. For instance, K-W-L Strategy develops the classroom situation, the students' motivation and attitude towards English lesson is getting better especially in reading class. Students become more active participants during the teaching learning process because they interacted with their friends in group. In other word, K-W-L strategy is a good strategy for reading comprehension because it can make the students participate well in the class. In other word, it makes the teacher should not spend more energy and time in giving lectures to the students. Meanwhile, let the students explore on their own in order to maximize their comprehension about the text or topic that given by the teacher.

To sum up, it can be stated that, the implementation of Know-Want-Learn (KW-L) strategy can be considered as precise as the same with the other study that already discussed in which their finding indicated that the pupils had positive perception on reading English text using know-want-learn (K-W-L) strategy. Specifically, to this present study, the implementation of know-want-learn strategy also closely followed with Ogle's explanation about the procedure of know-want-learn (K-W-L) strategy. Additionally, the implementation of know-want-learn (K-W-L) strategy also helped students to generate students' higher order thinking in order to understand the hortatory exposition text. It is in line with the finding discovered by Sinambela et al. (2015) who found that applying know- want-learn (KWL) in reading comprehension could help the students to promote critical thinking about what they read because this strategy could involve the students and make them more active in the class.

\section{CONCLUSION}

This qualitative research study aimed at observing the implementation of KnowWant-Learn (K-W-L) Strategy at SMA Negeri 3 Singaraja. This study conducted at SMA Negeri 3 Singaraja in academic year 2017/2018. This study focused on how K-WL strategy is implemented. Based on the theory which was stated in literature review, there are 6 indicators or steps which are also considered as standards to qualify the implementation of Know-Want-Learn (K-W-L) is closely followed or not. Those are, choose the topic and text., create a K-W-L chart, ask students to brainstorm words, 
terms, or phrases they associate with a topic. teacher and students record these association in the $\mathrm{K}$ column of their charts, ask students about what they want to know about the topic, have students read the text and fill out the L column of their charts and discuss the information that students recorded in the L column. Know-Want-Learn (KW-L) strategy brings beneficial impact to the students and also to the teacher. The use of K-W-L strategy is intended to involve the students in any activities for real use situation in real life. Besides, by implementing this strategy at the school, the teachers are able to set the reading purposes. Besides that, it helps the teachers to monitor the prior knowledge of the student before they get the new information and the teacher is able to know the students' knowledge after they read the passage or text.

\section{SUGGESTION}

There are some suggestions which can be proposed by the researcher as follows.

\section{For the teacher}

From the interview, the teachers stated that the implementation of Know-WantLearn (K-W-L) strategy in SMA Negeri 3 Singaraja is not perfect yet. Moreover, the teacher needs to maximize teaching and learning process of K-W-L strategy in order to make it become enjoyable to the students. Therefore, the students will be more motivated which will avoid the students' boredom in the classroom.

\section{For another researcher}

Finally, the researcher gives suggestion to other researcher who would like to conduct a research in the implementation of Know-Want-Learn (K-W-L) Strategy in Senior High School. The researcher hopes that the result of this study can be an additional reference for further researches because there was still weakness in teaching reading by using K-W-L strategy that implemented in SMA Negeri 3 Singaraja. The researcher hopes that, this strategy can be applied by other researcher in different level of students. Considering that this study still any lack, so the researcher hopes that the finding of this study will be used as starting point of the future research on similar problems.

\section{REFERENCES}

Brookhart, S. M. (2010). How to assess higher-order thinking skills in your classroom. $A S C D$.

Byrnes, H. 1998. Reading in the Beginning and Intermediate College Foreign Language Class. The National Capital Language Resource Center: Washington, DC. Retrieved on November 29, 2017

Heong, Y. M.,Othman, W.D.,Md Yunos, J., Kiong, T.T., Hassan, R., \& Mohamad, M.M. 2011. The Level of Marzano Higher Order Thinking Skills Among Technical Education Students . International Journal of Social and humanity, Vol. $1, N o$.

Nikmaturrahmah MS. 2016. The Implementation of $K$-W-L Strategy in Teaching Reading at The Second Grade of MTS N 2 Tanggamus. Last Retrieved: November, 21 st 2017.

Ogle, D. (1986). K-W-L: A teaching model that develops active reading of expository text. The Reading Teacher, 39, 564-570.

Pintrich, R.E., Romeo,G.C., \& Muller, S.A.B. 1999. Integrating Reading Strategies into the Accounting Curriculum. College Student Journal. 33(1): 77-82 
Punch Keith F, 2009, "Introduction to Research Methods in Education" available on http://gato-docs.its.txstate.edu/jcr:7ce2f55e-c73b-4ec3-a785dc380ec7406d/Creswell"

Sinambela, E. Manik, S and Pangaribuan, R.E. 2015. Improving Students' Reading Comprehension Achievement by Using $K-W-L$ Strategy. English Linguistics Research. Vol. 4, No. 3. Retrieved from: http://dx.doi.org/105430/elr.v4n3p13. Last time retrieved: November 24th, 2017. 